\title{
Analysis Adherence of Treatment and Sexual Behavior on Housewives with HIV/AIDS who Visits at Care Support and Treatment Service Cukir Public Health Center
}

\author{
Takariningsih $^{1}$, Katmini ${ }^{2}$ \\ ${ }^{1}$ Cukir Public Health Care \\ ${ }^{2}$ Master of Public Health Study \\ Program Institute of Health \\ Sciences Strada Kediri \\ Email: \\ takariningsih718@gmail.com
}

Received : October $4^{\text {nd }} 2021$

Accepted : October $15^{\text {rd }} 2021$

Published : November $27^{\text {th }} 2021$

\begin{abstract}
The use of ARV drugs aims to reduce HIV/AIDS-related deaths and increase life expectancy in addition to clinical improvement of people living with HIV. Antiretroviral apart from being an antiviral is also useful for preventing HIV transmission to sexual partners, as well as HIV transmission from mother to child. In the end, it is hoped that this will reduce the number of cases of people infected with new HIV in various countries. Nonadherence to taking ARVs and unsafe sexual behavior can lead to high transmission rates. This study aims to analyze medication adherence and sexual behavior among housewives with HIV/AIDS who visited the CST service at the Cukir Health Center. This study uses a qualitative method with a case study approach. Data was collected through in-depth interviews with semi-structured interview guidelines, and documentation with 18 PLWHA. Data analysis was carried out descriptively with triangulation methods and data analysis. The results of the analysis illustrate that there is still a lack of perception of vulnerability, perception of pain and perception of benefits for PLWHA, especially unsafe sex behavior of PLWHA.
\end{abstract}

Keywords: AIDS, HIV, compliance, sexual behavior, PLWHA, ARV therapy

Copyright (C) 2021 IIK STRADA Indonesia All right reserved.

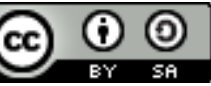

This is an open-acces article distributed under the terms of the Creative Commons AttributionShareAlike 4.0 International License.

\section{INTRODUCTION}

The problem of HIV/AIDS is a health problem that can threaten many countries, including Indonesia. The AIDS epidemic in Indonesia is like an iceberg phenomenon. Compliance or adherence to antiretroviral therapy is the key to successful HIV treatment because ARVs can inhibit the rate of virus multiplication (replication), but the number of PWLHA is increasing. access to ARV is still very low and the impact of non-adherence to antiretroviral therapy is one of the factors causing the loss of virological control, the emergence of drug resistance and the loss of further treatment options to the point of failure 
of therapy, costing money because they have to go up to line 2 and 3 therapy (Depkes RI 2014)

According to WHO data, only $36 \%$ of people with HIV who access ARV and $76 \%$ who experience suppression of their viral load 34\% disagree with ARV treatment in Indonesia. $26 \%$ of the total number of people living with HIV as many as 551,955 people, AIDS cases as many as 102,667. East Java Province was ranked 2nd after Papua reported 39,633 cases with details of HIV as many as 21390 cases and AIDS as many as 18,243 and those who died $(37.71 \%)$ or 14233 people.

In Jombang Regency cumulatively from 1997 to the end of 2020 as many as 1,791 people with HIV died (27\%). The death of PLWHA is generally due to being found late and has entered stage III - IV with various accompanying OIs, in addition to low adherence and high stigma, which causes them difficulties in accessing ARVs. Until the end of August 2020 the number of new HIV case findings from January to August 2020 as many as 125 people, $16 \%$ are adolescents aged $<19$ years, $31 \%$ have not received ARV therapy and $11 \%$ have died (P2 Data from the Jombang District Health Office August 2020) From the data obtained at the CST Clinic, Cukir Public Health Center, there are 101 PLWHA who access ARV treatment, with details of 24\% PLHA Women and 76\% PWLHA men. and as many as 20\% and people with HIV aged (> 50 years)

Based on Risk Group : Transgender 6\% ; MSM 47\% High-Risk Couples 35\% ; FSW $6 \%$ of the number of PLWHA found that $9 \%$ of people with HIV died and $1 \%$ changed treatment from the 101 PWLHA there were $70 \%$ of people with HIV with adherence $>95 \%$, 9\% with adherence (80-95\%) and 14\% of PWLHA with adherence < $80 \%$ and $7 \%$ of PWLHA passed the follow-up and died (LBPHA 2020)

The high cost of ARVs still affects distribution in several countries, while a response to suppress the number of viruses is needed adherence to the use of ARV drugs is $95 \%$, in this case PLWHA must drink regularly according to the type of medicine in a month, it is expected that no more than 3 forgets of a total of 60 pills (opinion of Peterson et al, 2000) Even a survey conducted by the Ministry of Health in 2010 stated that adherence $95 \%$ only $81 \%$ to achieve an undetectable viral load.

Non-adherence to ARV therapy can have the effect of drug resistance so that the drug cannot function or fail , as we know, the level of knowledge of PWLHA about HIV is still lacking and the absence of Supervisor taking medication and the lack of support from families or assistants causes the adherence of PWLHA to be less than expected (> $95 \%$ ) (Depkes RI 2012). 
One of the important steps to tackle HIV/AIDS is to increase the number of people living with HIV who take anti-retroviral (ARV) drugs. From the results of Y.Yulianda's 2017 study, it was proven that ARVs are effective in reducing HIV infection and found that $80 \%$ of HIV-infected patients who take ARVs regularly with 95\% adherence, blood levels of the virus are undetectable after six months of treatment and are the key to the success of HIV control. /AIDS is Supportive Care and Treatment (CST) with the provision of ANTI Retro Viral therapy

In addition to self-motivation and family support is support for PWLHA to be able to adapt well as well as individual readiness to change behavior in order to avoid a disease or minimize health risks. ARV therapy Social reasons, Stigma Cukir Public Health Center has prepared the CST Service Procedure with the aim of making it easier for PLWHA to get ART, which in the end is expected to improve the quality of life of PLWHA and increase PLWHA's adherence.

\section{METHOD}

This research was carried out at the CST Service of the Cukir Health Center in February 2021This research is a descriptive research with a qualitative approach. Qualitative methods can make it easier for researchers to describe drug adherence and sexual behavior in housewives who visit CST services at Cukir Health Center. The affordable population of Jombang Regency in this study were housewives with HIV/AIDS who visited CST services at the Cukir Jombang Health Center and were willing to do so interview ,totaling 18 people. The sample in this study were housewives with HIV who were treated at the CST Cukir Public Health Center who met the inclusion criteria. The research subjects were selected using the purposive sampling method which were not chosen randomly but based on certain considerations made by the researchers themselves, namely in accordance with the inclusion criteria set by the researchers. others due to teaching assignments, so a total of 18 subjects were interviewed. The samples obtained had met the inclusion criteria, including housewives with HIV/AIDS who came to visit the CST service of the Cukir Health Center who could read and write, housewives with HIV/AIDS who came to visit the PDP service of the Cukir Health Center. who have access to ARVs. in CST Cukir Public Health, housewives with HIV/AIDS who came to visit CST services at Cukir Public Health who were willing to become informants and were willing to become research subjects through approval by signing informed consent. The exclusion criteria were informants who were not willing to be interviewed and male PWLHA. The variables in this study were medication adherence and sexual behavior. The 
data collected in this study is the personal identity of the informants, recordings obtained through in-depth interviews. Interviews were conducted at the CST Service at Cukir Health Center with the help of 3 triangulation informants.

In-depth interviews were conducted with all subjects to see how their sexual compliance and behavior were. Data analysis was carried out in conjunction with the data collection process. The process of data analysis begins with collecting all interview data, direct observation, then documented in the form of transcripts and integrating the results of the analysis in descriptive form.

\section{RESULTS AND DISCUSSION}

Informants are 22-51 years old and domiciled in Jombang Regency. Elementary, middle and high school educational background. The average length of treatment is more than 3 years, there is 1 less than 1 year of treatment, five widows whose husbands died of HIV, five informants were partners with HIV while the other partners did not suffer from HIV. The results show the following themes:

Knowledge of HIV/AIDS and HIV/AIDS ARVs, adherence to medication, resistance to side effects, opportunistic infections and viral load

Most of the informants have poor knowledge and cannot properly explain what is meant by HIV and AIDS as stated by one of the informants as follows:

"Eemmm ...virus yang menular dan mematikan gitu ya bu penularan melalui hubungan seksual dan darah klo perbedaan hiv dan aids ga sama saja tah bu "(informan 1)"

Most of the informants have forgotten to drink according to the interview excerpts of the informants as follows:

"kadang kadang saya lupa minum obat karena ketiduran "(informan 8)"

Most of the informants do not know what resistance is as conveyed by the informant as follows:

\section{"Resisten karena putus nyambung obat bu "(informan 6)"}

Before making a prescription, consider the potential risks of the drug, the benefits that will be obtained, the various side effects of the drug that people with HIV feel at the beginning of treatment, but can overcome them. Only a small number of informants experienced side effects of treatment. This is in accordance with what the informant said as follows:

"Awal awal lebam diwajah dan gatal gatal"(informan 16)" 
Most of the informants do not know what is meant by Opportunistic Infections as stated by one of the informants as follows:

"Pernah dengar tapi tidak tahu bu "(informan 15)"

Adherence is directly proportional to physical condition, especially body weight and Viral Load test results, there are some people with HIV whose Viral Load test results are not suppressed, this is due to non-adherence to taking medication and supported by unsafe sexual behavior.Most of the informants do not know what is meant by Viral Load. This is in accordance with what was conveyed by the informant as follows:

\section{"Apa yaa bu...Tidak tahu bu "(informan 8)"}

Perception of Vulnerability Using Drugs / other drugs besides ARV Sexual activity Use of condoms Risk of transmitting HIV Risk of getting other diseases

Most of the informants have never consumed drugs according to the following interview excerpts:

“Tidak pernah bu ...ga berani minum obat lain "( informan 9)”

All of the informants only had sex with their husbands, although there were also women who had been sex workers either directly or indirectly and some were widowed claiming to have no partner other than their husbands. As quoted by the informant as follows:

\section{"Masih aktif berhubungan seksual ,ya dengan suami lah"( informan 1)" \\ "Masih .... ,ya dengan suami ga punya pasangan lain "( informan 2)”}

The use of condoms is identical to free sex and among people living with HIV is still very low, this is due to the unavailability of condoms at service centers and also feelings of discomfort and shame when they have to buy them in stores because they feel like they will be considered committing adultery.

most of the informants did not use condoms during sexual intercourse. according to what was conveyed by the informant as follows:

“Ga pernah pakai kondom bu ga nyangka klo suami saya positif dan tidak punya pasangan yang lain “(informan 4)”

A small number of informants admitted that they were at risk of transmitting HIV to their partners and contracting other diseases. The vulnerability in transmitting HIV was manifested in the behavior of using condoms in every sexual relationship by a small number of informants. The following is a snippet of the informant's statement:

"Takut suami ketularan makanya saya pake kondom "( informan 18)"

Perception of Severity, Risk of non-adherence to treatment / stopping treatment, Risk of death All informants stated that they were afraid if they stopped ARV therapy. most of the 
informants felt that they were healthy and did not have any disease. most of the informants felt that nothing would happen that would make them seriously ill. The following is an excerpt from the informant's statement:

"Nanti klo tambah sakit ga bisa diobati kemarin itu ga bisa ambil obat jadi bolong 3kali ya takut sebenere "( informan1)”

informants are ready to face death because that age has been chosen All by God Almighty. According to what the informant said as follows:

"Sudah siap karena semua orang pasti meninggal dengan atau tanpa ARV “(informan 6)"

Persepsi Hambatan , akses terhadap layanan PDP,Menjalani pengobatan

Semua odha mengatakan bahwa pengambilan ARV di Puskesmas Cukir mudah. Hal ini sesuai dengan yang disampaikan oleh informan sebagai berikut :

"lebih enak bu.....tidak ada kesulitan di cukir lebih enak "( informan 4)

most of the informants stated that there were no problems in taking ARVs. They can set a schedule for taking medication every day. Families also help remind when to take medication. The following is an excerpt from an informant's statement:

"Ga ada hambatan bu awal awal minum obatnya dipatahin jadi 2 karena kebesaren dengan melihat jam tapi saya mesti ingat klo waktunya minum obat “(informan 2)

Family Support Stigma and Discrimination Service Quality.

a small part of the information is open with the family and for couples who are both positive they keep the status for the two of them because they don't want to feel dizzy with family thoughts, only the following quote:

"Pertama kali yang saya beritahu ibu. Ya karena saya dekatnya sama ibu. Dukungan keluarga support, perhatiannya lebih, jangan telat minum obat, makan yang teratur, banyak berdoa. LSM juga membantu, ngingetin minum obat, ngingetin pas ada pertemuan, B Taka (Nakes) juga.selalu nelpon dan sms ", (Informan 1)

All informants stated that they had never experienced stigma and discrimination. This is because the informants closed the HIV status meeting except to their families and some were known to be alone with their husbands. The following is an excerpt from an informant's statement:

"Stigma dan diskriminasi belum pernah mengalami. Selama ini ga ada yang mengucilkan karena saya ga pernah cerita.tentang penyakit saya "(informan 1)"

Ease of service which is the provision of quality services to patients, especially people with $\mathrm{HIV}$, is very dependent on the alertness of service providers in responding to customer needs, 
must have the willingness to listen to complaints, suggestions, aspirations from the community so that they can satisfy patients.

Most of the informants stated that the services provided by health care facilities were good and there were no shortages. The following is an excerpt from an informant's statement:

"Pelayanannya baik, ga ada kekurangan."(informan 17)”

"Pelayanannya cepat, ga ngantri."(informan 2)"

\section{CONCLUSION}

Based on the discussion of the results of the research that has been described on "Analysis of Medication Compliance and Sexual Behavior in Housewives with HIV/AIDS who visit the Support Care and Treatment Services at the Cukir Health Center" the following results are obtained:

Knowledge of HIV/AIDS, most of the informants have poor knowledge about the meaning of HIV and AIDS. can't explain correctly what is meant by HIV and AIDS, what is the difference between the two and how the disease can be transmitted. Only able to explain that HIV and AIDS is a sexually transmitted disease

Adhrence: most of the informants have forgotten to take their medicine, some have forgotten for a few days, some have only had one day, some have overslept so it was too late to take their medicine.Resistensi : most of the informants do not know what resistance is

Side effects: only a small proportion of informants experience side effects at the beginning of treatment

Viral Load: most of the informants can't explain

Perceived Vulnerability, most of the informants have never used drugs and have never even taken drugs other than ARV

Sexual activity: all informants only had sexual relations with their husbands, although there were some who had been FSWs either directly or indirectly and some were widowed claiming that they had no other partner besides their husbands.

Condom use: most do not use condoms, some only occasionally use condoms during sexual intercourse

The risk of transmitting HIV: a small number of informants admit that they are at risk of transmitting HIV to their partners and contracting other diseases. The vulnerability in transmitting HIV is manifested in the behavior of using condoms in every sexual relationship by a small number of informants. 
Risk of contracting other diseases: most of the informants are afraid of the risk of disease that will be suffered if they do not comply with ARV therapy

Perception of Severity The informant's condition will get worse if he does not comply with the treatment. This can be seen from the statements of informants who are afraid of the severity of illness and even death and choose to be optimistic in living their lives. Most of the informants forgot to take their medicine, some forgot for a few days, some only took one day, some fell asleep so they were too late to take their medicine.

Risk of non-adherence to treatment/stopping treatment: all informants stated that they were afraid of stopping ARV therapy. Most of them feel that they are healthy and have no disease. Most of the informants felt that nothing would happen that would make them seriously ill Risk of death: all informants are ready to face death because that age has been predestined by God Almighty

Perception Barriers that cause a small proportion of non-adherence to treatment for people with HIV are the perceived side effects, lack of infrastructure to access ARVs and shame if their HIV status is known to others.

All informants stated that access to ARVs at the CST Cukir service was very easy. In undergoing treatment: most stated that there were no obstacles when taking ARVs. they can set a schedule for taking medication every day.

Family/social support: most of the informants stated that they received family support. courage to disclose HIV status to families in the hope of getting support from them. although a small proportion are not open with their families only to their husbands. All informants get support from NGOs and health workers.

Stigma and Discrimination All informants stated that they had never experienced stigma and discrimination, this was because the informants closed the HIV status meeting except to their families and some were only known to be alone with their husbands

Quality of Service, most of the informants stated that the services provided by health care facilities were good, the flow was not complicated and there were no shortages

\section{REFERENCE}

Bygrave H, Kranzer K, Hilderbrand K, et al, 2010, Trends in lost to follow up among immigrant workers on antireteroviral therapy in a community cohort in Lesotho, Plos One 5(10):e13198

Chi BH, Yiannoutsos CT, Westfall AO, Newman JE, Zhou J, Cesar C, et al: 2011, Universal Definition of Lost to Follow Up in HIV Treatment Progams: A Statistical Analysis of 111 Facilities In Africa, Asia, and Latin America,Plos Medicine 8 (10): 1-12.

Chris W. Green. 2013. Pengobatan untuk AIDS: Ingin Mulai?. Jakarta. Spiritia.

Dalal RP, Macphil C, Mahayi M, et al, 2008, Characteristic and Outcomes of Adult Patients Lost to Follow Up at an Antireteroviral Treatment Clinic In Johannesburg, South Africa, Journal of Acquired Immune Deficiency Syndrome 47(1): 101-107. 
Ditjen PP dan PL KementrianKesehatan RI, 2013,

Githa Fungi, dkk. 2013. Kepatuhan PengobatanARV Pada Pasien HIV AIDS Di RSUD Prof. Dr. Margono Soekarjo Purwokerto. Jurnal Media Farmasi. Vol. 10 No. 2. September 2013: 94-103.

Handayani SR, Yuniar Y, Mulyani AU, 2013, Pemaknaan Obat Antireteroviral (ARV) bagi Sekelompok Orang dengan HIV AIDS (ODHA) di Kota Cimahi, Bandung, Denpasar dan Kabupaten Badung, Buletin Penelitian Sistem Kesehatan, Volume 16, Nomor 3, Bulan Juli 2013: 227-235.

HIV dan AIDS Sekilas Pandang. Edisi Kedua. 2009. Komisi Penanggulangan AIDS Nasional.

Jurnal Berkala Ilmu Kesehatan Kulit dan Kelamin Fakultas Kesehatan Universitas Air Langga, Volume 22, Nomor 1, Bulan April 2010

Karen G, Barbara KR, Viswanath K, 2008, Health Behaviour and Health Education, Theory, Research and Practise 4th edition, Jossey-bass a wiley imprint.

Kasumu LO, Balogun MR. 2014. Knowledge and attitude Towards Antireteroviral Therapy and Adherence Pattern of HIV Patients in Southwest Nigeria, International Journal of Infection Control. Vol. 10i3.024.14: $1-8$.

Kementrian Kesehatan Republik Indonesia, 2011.

Kemenkes RI, Jakarta. 2014. Pedoman NasionalTatalaksanaKlinisInfeksi HIV danTerapi Antireteroviral.

Profil Kesehatan Indonesia Tahun 2013.Kemenkes RI, Jakarta. , 2012,

Latif F, Ida LM, Syafar M, 2014, Efek samping obat terhadap Kepatuhan Pengobatan Antireteroviral Orang dengan HIV/AIDS, Jurnal Kesehatan Masyarakat Nasional,Volume 9, No.2, November 2014, 101-6.

Moleong, J. Lexy, Dr. Prof. 2012. Metodologi Penelitian Kualitatif. Remaja Rosdakarya. Bandung.

Niven, Neil, 2012, Psikologi Kesehatan; Pengantar untuk Perawat dan Profesional Kesehatan Lain, EGC, Jakarta.

Notoatmojo, Soekidjo, Dr. Prof. , 2010, Ilmu Perilaku Kesehatan, Rhineka Cipa, Jakarta. , 2012. MetodologiPenelitianKesehatan. PT. RinekaCipta. Jakarta.

Nursalam MN, 2007, Asuhan Keperawatan pada Pasien Terinfeksi HIV/AIDS, Salemba Medika, Jakarta

Peltzer K, Ramlagan S, Khan MS, Gaeda B, 2011, The Social and Clinical Characteristics of Patients on Antireteroviral Therapy Who Are Lost To Follow Up In Kwazulu-Natal, South Africa: a Procpective Study, Journal des Aspects So Ciaux du VIH/SIDA 8(4): 179-186.

Peltzer K, Natalie FDP, Ramlagan S, Anderson J, 2010, Antireteroviral Treatment AdheranceAmong HIV Patients In Kwazulu-Natal- South Africa, BMC Public Health 10(111): 1-10.

Priyoto, 2014.Teori Sikap dan Perilaku Dalam Kesehatan.NuhaMedika. Yogyakarta

Ramadian O, Rixtriawan E, 2010, Pengaruh Efek Samping Antireteroviral (ARV) Lini I HIV/AIDS di Rumah Sakit Cipto Mangunkusumo (RSCM),

Laporan Penelitian, Indonesia: AIDS-INA, 2010

Rasmusen DN, Silva DT, Rodkjaer L, Oliveira I, et al, 2013, Barrier and Facilitators To Antireteroviral Therapy Adherance Among Patients With HIV In Bissau-Guinea Bissau: a Qualitative Study, African Journal of AIDS Research, DOI: 10-2989

Rosiana, AN, 2014, Faktor-faktor yang mempengaruhi lost to follow up pasien HIV/AIDS dengan terapi ARV di RSUP dr. Kariadi Semarang, Skripsi, Universitas Diponegoro Semarang.

Anggipita Budi Mahardining,2010 Hubungan Antara Pengetahuan, Motivasi, dan Dukungan Keluarga Dengan Kepatuhan Terapi ARV ODHA Jurnal Kesehatan Masyarakat http://journal.unnes.ac.id/index.php/kemas

Thukul Prasiddha Handayani, Zahroh Shaluhiyah, Syamsulhuda BM,2015 Perilaku ODHA dalam Pemeriksaan Berkala sebagai Upaya Perawatan dan Dukungan (Care and Support) di Kabupaten Pemalang

Abdul,Sisyahid, Kharis 2016, Faktor Yang Menyebabkan Terjadinya Ketidakpatuhan Terapi ANTIRETEROVIRAL (ARV) Pada Orang Dengan HIV/AIDS (ODHA) DI Kabupaten Pemalang

Titi Nurhayati, Yohana Wulan Rosaria, 2017 Faktor-Faktor Yang Berhubungan Dengan Orientasi Seksual Pada Remaja Program Studi Kebidanan Bogor Politeknik Kesehatan Kemenkes Bandung

Rihaliza1, Arina Widya Murni, Alfitri,2017 Hubungan Kepatuhan Minum Obat dan Jumlah CD4 Terhadap Kualitas Hidup Orang dengan HIV AIDS di Poliklinik Voluntary Counseling and Testing RSUP Dr M Djamil Padang

Abdul Kharis Sisyahid,Sofwan Indarjo, 2017 Halth Belief Model DAN Kaitannya Dengan Ketidakpatuhan TerapiI ANTIRETEROVIRAL Pada Orang Dengan HIV/AIDS 